2

I N S A N

\title{
PENGARUH ORIENTASI TUJUAN DAN PERSEPSI SISWA PADA KOMPETENSI GURU TERHADAP PROKRASTINASI AKADEMIK SISWA
}

\author{
BERNADETTA LISA ANDIKA PERMATASARI ${ }^{1 *} \&$ NUR AINY FARDANA ${ }^{2}$ \\ 1 Program Studi Magister Psikologi, Fakultas Psikologi Universitas Airlangga \\ 2Departemen Psikologi Perkembangan dan Pendidikan, Fakultas Psikologi Universitas Airlangga
}

\begin{abstract}
ABSTRAK
Penelitian ini bertujuan untuk mengetahui pengaruh orientasi tujuan dan persepsi siswa pada kompetensi guru terhadap prokrastinasi akademik. Metode yang digunakan adalah penelitian kuantitatif dengan subjek 132 siswa SMA Kristen Cita Hati Surabaya yang dipilih melalui teknik proportionate stratified random sampling. Alat pengumpulan data yang digunakan adalah kuesioner skala orientasi tujuan, persepsi siswa pada kompetensi pedagogik guru, dan prokrastinasi akademik siswa Analisis data yang digunakan adalah analisis regresi berganda. Hasil analisis regresi ganda melalui

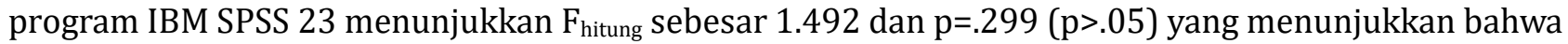
tidak terdapat pengaruh yang signifikan antara orientasi tujuan dan persepsi siswa pada kompetensi guru terhadap prokrastinasi akademik siswa.
\end{abstract}

Kata kunci: orientasi tujuan, persepsi siswa pada kompetensi guru, prokrastinasi akademik

\begin{abstract}
This research aimed to investigate the effect of goal orientation and students' perception of teacher competence on students' academic procrastination. This research used quantitative method with 132 subjects from Cita Hati Christian High School students and were selected through proportionate stratified random sampling. The data collection tool was a questionnaire of goal orientation, student's perception of teacher pedagogic competence, and student's academic procrastination. The data was analyzed by multiple regression analysis. The result of multiple regression analysis by IBM SPSS 23 showed the value of $\mathrm{F}=1.492$ and $\mathrm{p}=.299$ ( $\mathrm{p}>.05)$. The result showed that there is no significant effect between goal orientation and student's perception of teacher pedagogic competence to students' academic procrastination.
\end{abstract}

Keywords: goal orientation, , student's perception of teacher competence, academic procrastination 
INSAN Jurnal Psikologi dan Kesehatan Mental, 2017, Vol. 2(1), 77-83, doi: 10.20473/jpkm.v2i12017.77-83

Dikirimkan: 26 Januari 2017 Diterima: 31 Mei 2017 Diterbitkan: 26 Juli 2017

Editor: Rosatyani Puspita Adiati

*Alamat korespondensi: Jalan Jalan Airlangga 4-6, Surabaya, Jawa Timur 60286. Surel:

permatalisa13@yahoo.com

Naskah ini merupakan naskah dengan akses terbuka dibawah ketentuan the Creative Common Attribution License (http://creativecommons.org/licenses/by/4.0), sehingga penggunaan, distribusi, reproduksi dalam media apapun atas artikel ini tidak dibatasi, selama sumber aslinya disitir dengan baik.

\section{P E N D A H U L U A N}

Kualitas pendidikan di Indonesia seringkali fokus pada hasil prestasi akademik siswa. Namun, orang tua dan guru terkadang lupa bahwa ada beberapa faktor yang akan menghambat siswa dalam mencapai prestasi akademik, salah satunya adalah prokrastinasi. Steel (2004) menyatakan bahwa prokrastinasi merupakan perilaku menunda-nunda yang dilakukan secara sengaja terhadap suatu pengerjaan tugas, meskipun individu tersebut mengetahui dampak negatif yang akan terjadi. Penunda-nundaan inilah yang akan membuat siswa kesulitan mencapai prestasi belajar. Dalam konteks prokrastinasi akademik, kecenderungan penundaan tugas yang dilakukan seorang siswa bisa dilihat dari kepercayaan, persepsi, atau perasaan tertentu yang dimiliki siswa itu mengenai dirinya sendiri dalam ranah akademik (Andreas, 2007).

Prokrastinasi akademik yang dilakukan oleh siswa tidak akan lepas dari beberapa alasan. Menurut Solomon dan Rothblum (1984), faktor penyebab prokrastinasi dapat dikategorikan dalam dua faktor utama, yaitu takut gagal (fear of failure) dan menolak tugas dan malas (task averseness and laziness). Kedua faktor tersebut mucul dari dalam individu maupun dari luar individu itu sendiri. Ellis dan Knaus (dalam Ghufron \& Rini, 2010) menyatakan bahwa prokrastinasi merupakan salah satu masalah yang secara luas menimpa sebagian besar masyarakat dan siswa pada lingkungan yang lebih kecil. Perilaku proskrastinasi tentu saja akan memberikan dampak negatif pada siswa, diantaranya meningkatnya jumlah absen di kelas, nilai akademik menurun, dan paling parah adalah dikeluarkan dari sekolah. Burka \& Yuen (2008) menambahkan bahwa terdapat empat faktor yang menyebabkan munculnya perilaku prokrastinasi, yaitu; (a) kepercayaan diri yang rendah terhadap kemampuan untuk sukses; (b) keengganan mengerjakan tugas; (c) tujuan yang dicapai masih jauh; dan (d) kesulitan dalam selfregulation.

Burka dan Yuen (2008) menyatakan bahwa salah satu cara untuk mengetahui prokrastinasi adalah dengan melihat apakah perilaku tersebut menyusahkan bagi individu. Prokrastinator biasanya tidak akan mengalami penderitaan akibat dari penundaan yang dia lakukan. Terdapat tiga karakteristik perilaku yang menunjukkan sebuah prokrastinasi dan satu perilaku tambahan yang diungkapkan oleh Burka dan Yuen (2008), yaitu; (a) kesenjangan antara niat dan tindakan; (b) kesadaran diri yang rendah; (c) perilaku tidak disiplin; dan (d) perhatian yang mudah terganggu.

Fenomena prokrastinasi akademik yang selalu terjadi dari generasi ke generasi memunculkan pertanyaan, apakah yang sesungguhnya menyebabkan pelajar SMA melakukan perilaku prokrastinasi. Hingga saat ini, tanggapan yang serius mengenai fenomena penundaan di kalangan siswa belum begitu menjadi trending topic. Kebanyakan siswa dan guru menutup mata dan membiarkan perilaku yang jelas berdampak negatif tersebut. Siswa yang melakukan prokrastinasi akademik di sekolah biasanya tidak mendapatkan bantuan atau bimbingan untuk mengurangi perilaku tersebut. Guru hanya memberi

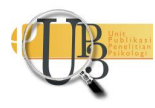


hukuman terhadap siswa tersebut dengan konsekuensi pengurangan nilai atau yang lainnya.

Perilaku tidak mau segera mengerjakan tugas dan menyelesaikan tugas yang telah dikerjakan biasanya dikaitkan dengan ada tidaknya motivasi belajar dalam diri siswa. Siswa memiliki motivasi untuk belajar dan mencapai prestasi belajar atau tidak berkaitan dengan orientasi tujuan yang dimiliki atau disebut goal orientation. Orientasi tujuan menjelaskan mengenai proses belajar dari kinerja siswa dalam menghadapi tugas-tugas akademik dan dalam lingkungan sekolah. Dalam hal ini, perhatian terfokus pada tujuan keterlibatan dalam perilaku berprestasi (Pintrich \& Schunk, 1996).

Ada dua jenis orientasi tujuan siswa menurut Ames (dalam Pintrich \& Schunk, 1996), yaitu task-involved orientation atau orientasi penguasaan tugas dan ego-involved orientation atau orientasi performansi. Orientasi tujuan penguasaan berarti tujuan siswa dalam belajar dicirikan oleh kepuasan ketika menguasai atau menyelesaikan tugas, disertai dengan tingkat efikasi yang tinggi, nilai tugas, minat, emosi positif, ketekunan yang tinggi, mengotimalkan penggunaan strategi kognitif dan metakognitif, dan menjalankan strategi belajar yang baik (Arias, 2004). Orientasi tujuan performansi berarti siswa lebih banyak memperhatikan kemampuannya dan kurang mengembangkan performansi yang lain, dalam melaksanakan tugas, fokusnya adalah lebih baik dari orang lain.

Selain orientasi tujuan, ada juga faktor lain yang menjadi penyebab prokrastinasi, yaitu persepsi siswa terhadap kompetensi guru. Mau tidak mau, proses belajar mengajar sangat berkaitan dengan orang yang menyampaikan materi dalam kelas. Dalam pembelajaran di kelas, guru merupakan seorang yang akan menggerakkan dan mengarahkan kelas tersebut menuju ke tujuan pembelajaran. Jadi, tidak dapat dipungkiri bahwa guru juga merupakan unsur penting dalam pembelajaran selain siswa. Apapun yang dimiliki atau dilakukan guru akan menjadi sorotan para siswa. Siswa bisa menilai guru itu baik atau tidak, bisa atau tidak, dari cara guru tersebut mengajar atau sekadar berperilaku.

Begitu pentingnya sosok guru bagi siswa, maka pemerintah membuat undang-undang bagi guru agar mereka memiliki kompetensi yang sesuai dengan kebutuhan siswa dan pendidikan di Indonesia. Berdasarkan PP no.19 tahun 2005 tentang standar pendidik dan tenaga pendidikan, seorang guru harus memiliki kompetensi sebagai agen pembelajaran, antara lain kompetensi pedagogik, kompetensi kepribadian, kompetensi profesional, dan kompetensi sosial. Keempat kompetensi tersebut nantinya akan dijabarkan pada indikator-indikator yang lebih jelas.

Kemampuan guru dalam memenuhi keempat kompetensi tersebut pastinya memiliki sumbangsih terhadap perilaku siswa dalam belajar. Menurut Cronbach (dalam Hamalik, 2009), jika individu mengagumi salah satu sifat seseorang, maka individu tersebut cenderung untuk mengagumi orang tersebut secara keseluruhan. Demikan juga halnya dengan persepsi siswa tentang kompetensi yang dimiliki seorang guru. Dalam penelitian ini, kompetensi yang akan dijadikan variabel adalah kompetensi pedagogik. Hal tersebut dikarenakan kompetensi pedagogik merupakan kemampuan pemahaman guru terhadap peserta didik, perencanaan dan pelaksanaan pembelajaran, evaluasi hasil belajar, dan pengembangan peserta didik sangat berkaitan dengan aktivitas, strategi, dan prestasi akademik siswa.

Menurut Maramis (dalam Sunaryo, 2002), persepsi adalah daya mengenal barang, kualitas atau hubungan, dan perbedaan antara hal ini melalui proses mengamati, mengetahui, atau mengartikan setelah panca inderanya mendapat rangsang. Tidak dapat dipungkiri, persepsi seseorang muncul karena adanya stimulus. Namun, prosesnya tidak berhenti begitu saja. Stimulus tersebut kemudian diteruskan dan proses selanjutnya merupakan proses persepsi.

Persepsi siswa terhadap kompetensi guru dalam kegiatan belajar mengajar di kelas ada yang positif dan ada yang negatif. Siswa yang memiliki persepsi positif terhadap gurunya, biasanya akan menyenangi pelajaran yang diberikan dan akan rajin mengikuti segala proses pembelajaran yang dilakukan oleh guru tersebut. Dalam kegiatan pembelajaran, siswa biasanya menunjukkan perilaku yang positif, misalnya 
memperhatikan materi yang disampaikan guru, ikut berpartisipasi aktif dalam diskusi, mau mengerjakan tugas yang diberikan guru, dan sebagainya. Sebaliknya, siswa yang memiliki persepsi yang negatif terhadap gurunya akan menunjukkan perilaku yang acuh, sibuk sendiri, menganggu temantemannya, malas mengerjakan tugas, dan lain-lain.

Berdasarkan pemaparan tersebut, prokrastinasi akademik merupakan suatu fenomena penting yang tidak seharusnya didiamkan. Prestasi siswa akan terhambat jika prokrastinasi tidak ditanggulangi dengan baik. Sebelum mengurangi tingkat prokrastinasi siswa, guru sebaiknya mengetahui penyebabpenyebab munculnya prokrastinasi.

Oleh karena itu, terdapat beberapa penelitian yang membahas mengenai prokrastinasi, salah satunya adalah penelitian yang dilakukan oleh Pramusanti (2011). Penelitian ini menunjukkan bahwa ada hubungan negatif yang sangat signifikan antara persepsi siswa terhadap kompetensi pedagogik guru dengan prokrastinasi akademik. Penelitian kedua yang membahas tentang prokrastinasi dilakukan oleh Howell dan Watson (2007). Penelitian ini meneliti hubungan antara prokrastinasi, orientasi tujuan berpestasi, dan strategi belajar dari 150 mahasiswa. Hasil penelitian ini menunjukkan bahwa prokrastinasi memiliki hubungan negatif dengan orientasi tujuan penugasan, tetapi memiliki hubungan yang positif dengan orientasi tujuan penghindaran penguasaan tugas.

Mengembangkan dari penelitian sebelumnya, penelitian ini akan membuktikan beberapa faktor yang mempengaruhi prokrastinasi, yaitu orientasi tujuan dan persepsi siswa pada kompetensi guru, khususnya kompetensi pedagogik. Kedua hal tersebut-orientasi tujuan dan persepsi siswa pada kompetensi guru merupakan beberapa faktor internal yang menjadi penyebab munculnya prokrastinasi akademik siswa.

\section{MET ODE}

\section{Partisipan}

Partisipan dalam penelitian ini adalah 132 siswa SMA Kristen Cita Hati Surabaya. Teknik sampling yang digunakan adalah dengan menggunakan stratified random sampling karena populasi dalam penelitian ini mempunyai anggota yang tidak homogen dan berstrata secara proporsional.

\section{Pengukuran}

Teknik pengumpulan data yang dilakukan dalam penelitian ini adalah kuesioner dengan menggunakan skala Likert. Instrumen penelitian untuk mengukur variabel dalam penelitian ini dikembangkan oleh peneliti sendiri. Untuk tingkat prokrastinasi akademik siswa, instrumen penelitian yang dikembangkan berdasakan pada ciri perilaku prokrastinasi yang dipaparkan oleh Burka dan Yuen (2005). Instrumen untuk mengukur orientasi tujuan siswa dikembangkan berdasarkan indikator orientasi tujuan yang dipaparkan oleh Ames dan Archer (1988). Instrumen untuk mengukur persepsi siswa terhadap kompetensi pedagogik guru dikembangkan dengan dasar indikator kompetensi guru berdasarkan UU RI no. 14 Tahun 2005 tentang Guru dan Dosen, Bab II pasal 2 ayat 1.

\section{Analisis Data}

Teknik analisis data yang digunakan adalah analisis regresi ganda. Analisis regresi ganda adalah alat untuk meramalkan nilai pengaruh dua variabel bebas atau lebih terhadap satu variabel terikat (untuk membuktikan ada tidaknya hubungan fungsional atau hubungan kausal antara dua atau lebih variabel bebas). Dalam penelitian ini, kegunaan analisis regresi ganda untuk mengetahui ada tidaknya pengaruh INSAN Jurnal Psikologi dan Kesehatan Mental 2017, Vol. 2(1), 77-83

doi: 10.20473/jpkm.v2i12017.77-83 
yang signifikan antara orientasi tujuan dan persepsi siswa terhadap kompetensi guru dengan prokrastinasi akademik siswa SMA Kristen Cita hati Surabaya. Cara penghitungan statistik dalam penelitian ini dibantu dengan program IBM SPSS Statistics 23.

\section{HAS I L P E N ELITIA N}

Dari hasil analisis regresi, peneliti memperoleh nilai $\mathrm{F}_{\text {hitung }}$ sebesar 1.492 dengan probabilitas atau nilai signifikansi sebesar .229 ( $\mathrm{p}<.05)$. Oleh karena itu, hipotesis penelitian ini ditolak karena tidak terdapat pengaruh yang signifikan secara simultan (bersama-sama) antara orientasi tujuan dan persepsi siswa pada kompetensi guru terhadap prokrastinasi akademik siswa.

Nilai $t_{\text {hitung }}$ untuk variabel orientasi tujuan $\left(\mathrm{X}_{1}\right)$ adalah sebesar -1.522 dengan taraf signifikansi .130 $(\mathrm{p}<.05)$. Oleh karenanya, tidak ada pengaruh yang signifikan antara variabel orientasi tujuan terhadap variabel prokrastinasi akademik siswa. Nilai thitung untuk variabel persepsi siswa pada kompetensi pedagogik guru $\left(\mathrm{X}_{2}\right)$ adalah sebesar 0.742 dengan taraf signifikansi .459 ( $<$ <.05). Maka, tidak ada pengaruh yang signifikan antara variabel persepsi siswa pada kompetensi pedagogik guru terhadap variabel prokrastinasi akademik siswa.

\section{I S K U S I}

Hipotesis dalam penelitian ini adalah terdapat pengaruh yang signifikan antara orientasi tujuan berprestasi dan persepsi siswa pada kompetensi guru terhadap prokrastinasi akademik siswa. Tujuan dari penelitian ini untuk mengetahui seberapa besar pengaruh variabel orientasi tujuan dan persepsi siswa pada kompetensi pedagogik guru terhadap perilaku prokrastinasi siswa. Berdasarkan data penelitian yang dianalisis, peneliti akan membahas hasil penelitian dari aspek teoritis dan praktiknya.

Prokrastinasi akademik adalah perilaku penundaan pada tugas akademik yang dilakukan secara sadar dengan melakukan aktivitas lain yang menyenangkan, tidak bertujuan, dan tidak memperhatikan waktu sehingga menimbulkan akibat negatif atau kerugian pada pelakunya. Burka dan Yuen (2008) menyatakan bahwa terdapat empat faktor yang menyebabkan munculnya perilaku prokrastinasi, yaitu; (a) kepercayaan diri yang rendah terhdap kemampuan untuk sukses; (b) keengganan mengerjakan tugas; (c) tujuan yang dicapai masih jauh; dan (d) kesulitan dalam self-regulation. Kepercayaan diri yang rendah terhadap kemampuan untuk sukses dan tujuan yang dicapai masih jauh merupakan bagian dari orientasi tujuan, sedangkan keengganan mengerjakan tugas berhubungan dengan persepsi siswa, khususnya dalam hal ini adalah persepsi siswa pada komptensi pedagogik guru.

Ditolaknya hipotesis yang diajukan peneliti dimungkinkan karena adanya faktor lain yang lebih dominan seperti yang dinyatakan oleh Solomon dan Rothblum (1984) bahwa terdapat dua faktor utama yang mempengaruhi prokrastinasi, yaitu takut gagal dan penolakan terhadap tugas. Faktor takut gagal ini berhubungan dengan selalu merasa cemas, penetapan standar performa yang terlalu tinggi atau perfeksionisme, kesulitan membuat keputusan, ketergantungan dengan orang lain, rendahnya tingkat kepercayaan diri individu, kurangnya penerimaan, dan takut akan keberhasilan. Faktor penolakan terhadap tugas berhubungan dengan perasaan terancam akan tugas, kecenderungan untuk merasa kelelahan, pemberontakan terhadap otoritas, kemalasan, pengambilan risiko, dan pengaruh teman sebaya.

Burka dan Yuen (2004) juga menyatakan faktor lain yang mempengaruhi munculnya perilaku prokrastinasi, yaitu kepercayaan diri yang rendah terhadap kemampuan untuk sukses, keengganan mengerjakan tugas, tujuan yang akan dicapai masih jauh, dan kesulitan dalam self-regulation. Kemudian, Burka dan Yuen (2004) menambahkan bahwa prokrastinasi memiliki relasi yang kuat dengan

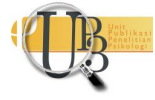


manajemen waktu yang buruk, kesadaran diri yang rendah, perilaku tidak disiplin, dan perhatian yang mudah terganggu.

Hasil penelitian menunjukkan bahwa kecenderungan prokrastinasi yang dilakukan partisipan bukan karena pengaruh dari faktor orientasi tujuan dan persepsi siswa pada kompetensi guru. Hal tersebut didukung oleh hasil wawancara kepada beberapa subjek siswa setelah analisis data ini dilakukan. Kecenderungan untuk tidak menyelesaikan tugas biasanya disebabkan oleh kurangnya kemampuan untuk mengatur waktu, malas, dan kondisi sekitar lingkungan yang tidak mendukung subjek untuk menyelesaikan tugas, misalnya diajak teman untuk pergi jalan-jalan.

Berdasarkan pemaparan tersebut, maka hasil penelitian ini tidak terbukti dimungkinkan karena adanya faktor lain yang lebih berpengaruh atau dominan terhadap kecenderungan prokrastinasi akademik. Peneliti menyadari bahwa penelitian yang dilakukan ini masih terdapat banyak kelemahan, baik dalam penyusunan maupun pelaksanaan penelitian, terutama dalam distribusi kuesioner. Salah satu kelemahan metode survei dengan alat pengumpulan data berupa kuesioner adalah peneliti tidak dapat mengontrol pilihan jawaban responden. Dengan jumlah responden 132 siswa, tidak sedikit siswa yang menjawab secara tidak serius, misalnya menjawab setuju atau sangat setuju pada semua aitem sehingga merusak distribusi. Hasil jawaban siswa tersebut memberikan dampak pada hasil penelitian ini. Selain itu, keterbatasan penelitian ini adalah peneliti hanya melihat faktor orientasi tujuan dan persepsi siswa pada kompetensi pedagogik guru sebagai faktor yang mempengaruhi prokrastinasi, tetapi secara teoritis terdapat banyak faktor yang mempengaruhi prokrastinasi akademik.

\section{S I M P U L A N}

Berdasarkan hasil penelitian dan pembahasan yang diperoleh, peneliti menyimpulkan bahwa tidak terdapat pengaruh yang signifikan antara variabel orientasi tujuan dan persepsi siswa pada kompetensi pedagogik guru terhadap prokrastinasi akademik. Penelitian ini juga menunjukkan bahwa variabel orientasi tujuan memiliki pengaruh yang lebih besar terhadap prokrastinasi akademik siswa daripada variabel persepsi siswa pada kompetensi pedagogik guru.

\section{PUSTAKA ACUAN}

Ames, C., \& Archer, J. (1988). Achievement goals in the classroom: Students' learning strategies and motivation processes. Journal of Educational Psychology, 80(3), 260.

Andreas. (2007). Hubungan Konsep Diri Akademik dengan Prokrastinasi Akademik pada Mahasiswa. Skripsi. Psikologi UI.

Arias, J.F. (2004). Recent Perspective in the Study of Motivation: Goal Orientation Theory. Electronic Journal of Research in Educational Psychology. Department of Developmental Psychology and Universidad de Almeria.

Burka, J.B., \& Yuen, L.M. (2008). Procrastination: Why You Do It: What to Do about It Now. Cambridge: Da Capo Press.

Ghufron, N. \& Rini, R. S. (2010). Teori-Teori Psikologi. Yogyakarta: Az-Ruzz Media.

Hamalik, O. (2009). Proses Belajar Mengajar. Bandung: Bumi Aksara.

Howell, A. J., \& Watson, D. C. (2007). Procrastination: Associations with achievement goal orientation and learning strategies. Personality and Individual Differences, 43(1), 167-178.

Pramusanti, N. (2012). Hubungan Antara Persepsi Siswa terhadap Kompetensi Pedagogik Guru dengan INSAN Jurnal Psikologi dan Kesehatan Mental

2017, Vol. 2(1), 77-83

doi: $10.20473 /$ jpkm.v2i12017.77-83

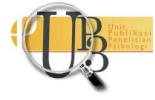


Prokrastinasi Akademik pada Siswa SMP Al-Islam 1 Surakarta. Skripsi. Universitas Muhammadiyah Surakarta.

Pintrich, P.R. \& D.H. Schunk. (1996). Motivation in Education, Theory, Research, and Application. Ohio: Prentice Education. Solomom, L.J. \& Rothblum, E.D. (1984). Academic Procrastination: Frequency and Cognitive-Behavioral Correlates. Journal of Counseling Psychology, 31, 504-510.

Solomon, L. J., \& Rothblum, E. D. (1984). Academic procrastination: Frequency and cognitive-behavioral correlates. Journal of Counseling Psychology, 31(4), 503-509.

Steel, P. (2004). The Nature of Procrastination: A Meta-Analytic and Theoretical Review of Quintessential Self-Regulatory Failure. Canada: University of Calgary.

Sunaryo. (2002). Psikologi untuk Keperawatan. Jakarta: Penerbit Buku Kedokteran EGC. 